\title{
The effect of different temperature on the viability and fertility of Drosophila
} melanogaster

\author{
Abolhasan Rezaei \\ Department of Genetics-School of Basic Science, Tonekabon Branch, Islamic Azad \\ University, Tonekabon, Iran \\ a.rezaei@tonekaboniau.ac.ir
}

\section{ABSTRACT}

Many studies found that the temperature has affected the fecundity and fertility in the female of Drosophila melanogaster. In this study we used male of 2-3 days age old and female of 5-6 days age old for studies of temperatures on the male reproductive performance and female fitness traits. In related to be compared three temperatures from low $\left(15^{\circ} \mathrm{C}\right)$ temperature middle temperature $\left(22^{\circ} \mathrm{C}\right)$ and high temperature $\left(29^{\circ} \mathrm{C}\right)$, results were analysed by SPSS software for getting mean value , ANOVA variation and correlation relationship. In this regard, females which exposure to high temperature, among of egg laid and offspring produce (fecundity and fertility, respectively) less than middle and low temperature, that these results were significant, $p$ value $<0.000$, between male and female with temperature and also between fecundity and fertility. The results of correlation relationship are shown; there was a significant Pearson correlation between three temperatures (low, middle and high) with the rate of egg laid and egg hatchability.

Keywords: Drosophila melanogaster, female mating, Fecundity, Fertility.

\section{INTRODUCTION}

The temperature is important in life cycle of Drosophila melanogaster, this factor will determine physiological function and numerous mechanisms compensating for temperature variation (Cossins and Bowler, 1987; Precht et al., 1973; Leather et al., 1993). Temperature function also has been investigated and characterized for extreme conditions and tolerance of cold and heat stress. (Hoffmann and Parsons, 1991, 1997; Zatsepina et al., 2001; Hoffmann et al., 2003). Parsons 1973 and David 1971 , proposed that male flies by chronic exposure of hot temperature $\left(29^{\circ} \mathrm{C}\right)$, the fertility was very less, however, these males after a few days at a lower temperature could recover fertility element. This phenomenon, also reported by (David et al., 1983). Temperature also plays an important role in reproductive performance and fitness components such as female fecundity, fertility and male mating ability in Drosophila melanogaster. It is critical condition at low and high temperatures. (Mckenzie, 1975; Parsons, 1978; Schnebel and Grossfield, 1986). The high temperature can exert evolutionary effect on the body size, genetically diverse. (David and Bocquet 1975; David et al. 1983; Lemeunier et al. 1986; Coyne and Beecham 1987;James et al. 1995), Also, there is evidence from laboratory studies of ectothermal condition that compared between cold and warm temperature. Cold adapted lines about oviposition and egg laid more than the warm adapted when reared at a common temperature, irrespective of whether the comparison is conducted in the warm or the cold environment. (Anderson 1966, 1973; Cavicchi et al. 1985, 1989; Partridge et al. 1994). 
In the present study, the hypothesis effective of temperature on the reproductive performance, the temperatures evolved at lower , middle and warmer temperature that act on the female and male fitness traits were studied. In contrast, the females derived from cooler environment produced more eggs and also more offspring than females derived from warmer environments. Similar results also are shown in Drosophila pseudoobscura (Dobzhansky, 1935), Drosophila melanogaster (Tantawy and El Helw, 1970).These studies demonstrate adaptation flies in reared cold temperature more than warm temperature. Here we aimed, the effect of low, middle and warm temperatures on the rate of reproductive performance such as female egg laid, egg hatchability, and male mated performance in Drosophila melanogaster for stage of young days aged.

\section{MATERIALS AND METHODS}

Isofemale flies: The isofemale lines namely Oregan $\mathrm{K}$ obtained from the National Drosophila Stock Centre, Department of Zoology (UOM)-India. These flies were used to study of temperature effect on the male mating performance and female fitness components. The flies were cultured and using wheat cream agar medium at $70 \%$ humidity and relative temperature including, $15^{\circ} \mathrm{C}, 22^{\circ} \mathrm{C}$ and $29^{\circ} \mathrm{C}$. Twenty flies quarter pint milk bottle (250 ml) were maintained using 12:12 hour light/dark cycle. These flies were kept in vial by separately male and female and aged as required for next experiments.

Exposure to different temperature: To test the effect of temperature on male mating ability and female fitness performances were used experiments in three different temperatures, including, $15^{\circ} \mathrm{C}, 22^{\circ} \mathrm{C}$ and $29^{\circ} \mathrm{C}$. The male and female flies after egg eclosion, immediately were separated male and female in new vials. The males at this study had 2-3 days age old for mating with virgin females that had 5-6 days old age. For studies of female components fitness, virgin males and virgin females were kept for 24 hours in the vial for mating with them. The components fitness such as egg laid and hatchability (fecundity and fertility, respectively), every three hours egg laid was recorded. The eggs laid in different temperatures were indicated for fecundity performance and also the produce of offspring was indicated for fertility components.

Statistical analysis: The percent of, female reproductive performance such as, fecundity and fertility were planned and analyzed by an SPSS software program (version 10.1) with the average number of eggs per female in the fifty replicates as dependent to variable age and fertility as dependent variable. These parameters were computed by mean value, one way ANOVA variation, regression and correlation index.

\section{RESULTS}

Fitness components: The fitness components were measured and recorded including, fecundity and fertility.

The effect of temperature on the fecundity: Fecundity in $15^{\circ} \mathrm{C}$ was measured, the female flies 5-6 days old age with 2-3 days male age after mating, the eggs laid were counted every day. Also in $22^{\circ} \mathrm{C}$ and $29^{\circ} \mathrm{c}$, eggs were counted and recorded, in comparison with mean value is shown, the eggs laid in $15^{\circ} \mathrm{C}$ more number than $29^{\circ} \mathrm{C}$ and in $22^{\circ} \mathrm{C}$ rate of eggs laid, higher than other temperature (Table 1). The results also were compared by ANOVA variation in three temperatures. There were between three temperatures $\left(15^{\circ} \mathrm{C}, 22^{\circ} \mathrm{C}\right.$ and $29^{\circ} \mathrm{C}$, respectively) with male age (2-3 days old aged) 
and female age (5-6 days old aged) a significant, $p$ value $<0.001$.(Table 2). Moreover, there was a significant $p$ value $<0.001$ between temperatures (Table 2 ). The results of fecundity by mean value also are shown in Fig.1, length of Graph in temperature of $22^{\circ} \mathrm{C}$ was longer than $15^{\circ}$ and $29^{\circ} \mathrm{C}$.

Table 1: The mean value of egg laid and egg hatchability was compared by SPSS software, results are shown, the rate of female fecundity and fertility in temperature of $22^{\circ} \mathrm{C}$ was more than $15^{\circ} \mathrm{C}$ and $22^{\circ} \mathrm{C}$.

\begin{tabular}{|cc|c|c|}
\hline & Temperature & Fecundity & Fertility \\
\hline 1.00 & Mean & 203.2600 & 85.4000 \\
& $\mathrm{~N}$ & 50 & 50 \\
& Std. Error of Mean & 11.96876 & 5.46760 \\
\hline 2.00 & Mean & 399.6400 & 223.7600 \\
& $\mathrm{~N}$ & 50 & 50 \\
& Std. Error of Mean & 11.85004 & 9.73165 \\
\hline 3.00 & Mean & 85.4000 & 53.9600 \\
& $\mathrm{~N}$ & 50 & 50 \\
& Std. Error of Mean & 5.46760 & 2.35675 \\
\hline Total & Mean & 229.4333 & 121.0400 \\
& $\mathrm{~N}$ & 150 & 150 \\
& Std. Error of Mean & 12.12960 & 7.12604 \\
\hline
\end{tabular}

Table 2: Female fecundity and fertility were compared by ANOVA variation between three temperatures, including, low $\left(15^{\circ} \mathrm{C}\right)$, middle $\left(22^{\circ} \mathrm{C}\right)$ and high $\left(29^{\circ} \mathrm{C}\right)$, there were significant records at level of $\mathrm{P}<0.000$ between temperature with female fecundity and fertility.

\begin{tabular}{|cc|c|c|c|c|c|}
\hline & & Sum of Squares & df & Mean Square & F & Sig. \\
\hline \multirow{2}{*}{ Fecundity } & Between Groups & 2520047.693 & 2 & 1260023.847 & 241.099 & .000 \\
& Within Groups & 768245.140 & 147 & 5226.157 & & \\
& Total & 3288292.833 & 149 & & & \\
\hline \multirow{2}{*}{ Fertility } & Between Groups & 816066.720 & 2 & 408033.360 & 188.100 & .000 \\
& Within Groups & 318877.040 & 147 & 2169.232 & & \\
Total & 1134943.760 & 149 & & & \\
\hline
\end{tabular}



Fig.1: The parameters of fecundity (fec.) and fertility (fert.) from left to right, also, every parameter is three graph that including, low temperature $\left(15^{\circ} \mathrm{C}\right)$, middle temperature $\left(22^{\circ} \mathrm{c}\right)$, high temperature $\left(29^{\circ} \mathrm{C}\right)$. Values are given as means $\pm \mathrm{SE}(\mathrm{N}=50)$. The length of graphs indicates the variation activity in different temperatures. 
The effect of temperature on the fertility: The results of fertility, between temperatures $\left(15^{\circ} \mathrm{C}, 22^{\circ} \mathrm{C}\right.$ and $\left.29^{\circ} \mathrm{C}\right)$, are shown, that mean $p$ value $<0.000$ was significant.(Table 1). These results also were compared by ANOVA variation, the among of produce flies from $22^{\circ} \mathrm{C}$, is higher than $15^{\circ} \mathrm{C}$ and $29^{\circ} \mathrm{C}$ that a significant $p$ value $<0.000$ between male age, female age and different temperatures (Table 2). These results also in Fig. 1 show, the length of graph in temperature of $22^{\circ} \mathrm{C}$ is longer than other temperatures were mentioned.

Regression and Correlation between Parameters: Repeated-measures by regression and correlation for flies revealed a main effect of temperature on the male reproductive performance and female fitness traits. In related to, the results in Table 3 are shown, following the results, there was a Pearson correlation relationship between fecundity, fertility and temperature. In related to Pearson correlation between fecundity and fertility was significant at the $0.795^{* *}$ level, between fecundity and temperature at the $0.325^{* *}$, between fertility and temperature, at the $0.148^{*}$ level. There was a significant variation, between fecundity and fertility, $\mathrm{p}$ value $<0.000$. Between fecundity and temperature, pvalue $<0.000$, between fertility and temperature, $\mathrm{p}$ value $<0.000$. (Table 3).

Table 3: Female fecundity and fertility were compared between three temperatures, including, low $\left(15^{\circ} \mathrm{C}\right)$, middle $\left(22^{\circ} \mathrm{C}\right)$ and high $\left(29^{\circ} \mathrm{C}\right)$, there were significant records at level of $\mathrm{P}<0.000$ between temperature with female fecundity and fertility. In comparison by Pearson correlation also, there were significant records between temperature with fecundity and fertility.** Correlation is significant at the 0.01 level (1-tailed). *. Correlation is significant at the 0.05 level (1-tailed).

\begin{tabular}{|lc|c|c|c|}
\hline & & Fecundity & Fertility & Temperature \\
\hline Fecundity & Pearson Correlation & 1 & $.795^{* *}$ & $-.325^{* *}$ \\
& Sig. (1-tailed) & & .000 & .000 \\
& $\mathrm{~N}$ & 150 & 150 & 150 \\
\hline Fertility & Pearson Correlation & $.795^{* *}$ & 1 & $-.148^{*}$ \\
& Sig. (1-tailed) & .000 & & .036 \\
& $\mathrm{~N}$ & 150 & 150 & 150 \\
\hline Temperature & Pearson Correlation & $-.325^{* *}$ & $-.148^{*}$ & 1 \\
& Sig. (1-tailed) & .000 & .036 & \\
& $\mathrm{~N}$ & 150 & 150 & 150 \\
\hline
\end{tabular}

\section{DISCUSSION}

Exposure of high temperature: We have studied regards factors that influence the temperature on the fitness traits and reproductive performance in male and female flies. In related to, we studied the effect of temperature on oviposition had exposure on the three temperatures, means, cold, middle and high temperature, the difference in the mean number of eggs between $15^{\circ} \mathrm{C}, 22^{\circ} \mathrm{C}$ and $29^{\circ} \mathrm{C}$ in Drosophila melanogaster is significant. These results also are the same with other species of Drosophila, including Drosophila ananassae, that has been utilized during the present study and has been used for study of effect of temperature on oviposition (McKenzie, 1975; Parsons, 1978; Schnebel\& Grossfield, 1986). At low temperature the range of 12$20^{\circ} \mathrm{C}$, the among of eggs laid are severely reduced (Mckenzie, 1975; Parsons, 1978). The high temperature, at range of $28^{\circ} \mathrm{C}$ to $30^{\circ} \mathrm{C}$, also among of reduction is more than middle temperature. (David \& Clavel, 1969). In our researches, high temperature $\left(29^{\circ} \mathrm{C}\right)$ the among of egg laid was very less than middle and also low temperature, also the period of egg laid in low temperature $\left(15^{\circ} \mathrm{c}\right)$, is longer than middle and high temperature. Also among of egg laid in daily, low temperature is less than middle and 
high temperature, in opposite of that, high temperature period of egg laid is shorter than middle and low temperature, also the results of longevity in females, low temperature longer than middle and high temperature, in females that exposure of high temperature earlier were dead. These suggests that temperature-dependent oviposition is an important factor affecting egg laid in Drosophila, because of limited physiological capabilities of the organism at low temperature.

Fertility element: Fertility element, including effect of male-female age and temperature on the hatchability, viability, reproductive capacity. In Drosophila melanogaster, population, normal temperature, is necessary for developmental and physiological processes. (Feder et al., 1996; Kamping \& Van Delden, 1999). Also, Kamping 1999, found, the flies that exposure of high temperature stress, (around $33^{\circ} \mathrm{C}$ ), highest mortalities and strongest karyotypic effects when the preceding of larval development occurred at $33^{\circ} \mathrm{C}$, because of limited physiological capabilities of the organism at a low temperature.(Kamping, 1999). In our studies, the among of egg hatchability, as compared in temperature of $29^{\circ} \mathrm{C}$ was less than $22^{\circ} \mathrm{C}$ and $15^{\circ} \mathrm{C}$. Results are shown however between male and female with temperature was significant, but also, in Figure 1, from temperature of $22^{\circ} \mathrm{C}$ to $29^{\circ}$ the length of graph longer than from temperature of $15^{\circ} \mathrm{C}$ to $22^{\circ} \mathrm{C}$. So, the female flies had adapted when at exposure of cold temperature $\left(15^{\circ} \mathrm{C}\right)$ than hot temperature $\left(29^{\circ} \mathrm{C}\right)$. And in middle temperature is best for getting higher offspring in Drosophila mekanogaster.

\section{ACKNOWLEDGMENTS}

This work had financially supported by the Research Council of Islamic Azad University Tonekabon Branch- Iran.

\section{REFERENCES}

Anderson, W. W. (1966). Genetic divergence in M. Vetukhiv's experimental populations of Drosophila pseudoobscura. Genet. Res. Camb., 7:255-266.

Anderson, W. W. (1973). Genetic divergence in body size among experimental populations of Drosophila pseudoobscura kept at different temperatures. Evolution., 27: 278-284.

Cossins, A. and K. Bowler. (1987). Temperature Biology of Animals. London: Chapman and Hall.

Coynej, A. and Beecham, E. (1987). Heritability of two morphological characters within and among natural populations of Drosophila melanogaster. Genetics., 117:727-737.

Cavicchsi, S.; Guerra, D.; Giorgi, G. and Pezzoli, C. (1985). Temperature- related divergence in experimental populations of Drosophila melanogaster. I. Genetic and developmental basis of wing size and shape variation. Genetics., 109: 665-689.

Cavicchsi, S.; Guerra, D.; Natali, V.; Pezzoli C. and Giorgi G. (1989). Temperaturerelated divergence in experimental populations of Drosophila melanogaster.

David, J. R.; Arens, M. F. and Cohet, Y. (1971). Stérilité mâle à haute température chez Drosophila melanogaster: nature, progressivite et réversibilité des effets de la chaleur. C. R. Acad. Sci. Paris., 272: 1007-1010.

David, J. R. and BOCQUET, C. (1975). Similarities and differences in latitudinal adaptation of two Drosophila sibling species. Nature., 257:588-590. 
David, J. and Clavel, M. F. (1969). Influence de la temperature sur le nombre, le nombre, le pourcentage d'eclosion et al. tail le des oenfs pondus Par $D$. melanogaster. Ann. Soc. Entomol. Fr., 5: 161-177.

Dobzhanskty, (1935). Fecundity in Drosophila pseudoobscura at different temperatures. J. Exp. Zool., 71:449-464.

David, J. R.; Allemand, R.; Van Herrewege, J. and Cohet, Y. (1983). Ecophysiology: a biotic factors. In Genetics and Biology of Drosophila (ed. M. Ashburner, H. L. Carson and J. N. Thompson), pp. 105-170. New York: Academic Press.

Feder, M. E. (1996). Ecological and evolutionary physiology of stress proteins and the stress response: The Drosophila melanogaster model. In I. A. Johnston, A. F. Bennett (Eds.), Animals and temperature: Phenotypic and evolutionary adaptation (79-102). Cambridge University Press, Cambridge, U.K.

Hoffmann, A. A. and Parsons, P.A. (1991). Evolutionary Genetics and Environmental Stress. Oxford: Oxford University Press.

Hoffmann, A. A. and Parsons, P.A. (1997). Extreme Environmental Change and Evolution. Cambridge: Cambridge University Press.

Hoffmann, A.; Sorensen, J. G. and Loeschcke, V. (2003). Adaptation of Drosophila to temperature extremes: bringing together quantitative and molecular approaches. J. Therm. Biol., 28: 175-216.

James, A. C.; Azevedo, R. and Partridge, L. (1995). Cellular basis and developmental timing in a size cline of Drosophila melanogaster. Genetics., 140:659-666.

Kamping, A. and Van Delden, W. (1999). A long-term study on interactions between the Adh and aGpdh allozyme polymorphisms and the chromosomal inversion In (2L)t in a seminatural population of D. melanogaster. J. Evol. Biol., 12: 809821.

Krebs, R. A. and Loeschcke, V. (1994). Effects of exposure to short-term heat stress on fitness components in Drosophila melanogaster. J. Evol. Biol., 7: 39-49.

Lindsley, D. L. and Zimm, G.G. (1992). The Genome of Drosophila Melanogaster. Academic Press, San Diego, CA.

Leather, S.; Walters, K. and Bale, J. (1993). The Ecology of Insects Overwintering. Cambridge: Cambridge University Press.

Lemeuniefr, J.; David, R.; Tsacas, L . and Ashburner, M. (1986). The melanogaster species group. pp. 147-256 in M. Ashburner, H. L. Carson and J. M. Thompson, ed. Genetics and biology of Drosophila. Academic Press, London.

Mckenzie, J. A. (1975). The influence of low temperature on survival and reproduction in populations of Drosophila melanogaster. Aust. J. Zool., 23: 237-247.

Parsons, P. A. (1978). The effect of genotype and temperature on longevity in natural populations of Drosophila melanogaster. Experimental Gerontology., 13:167169.

Parsons, P. A. (1973). Genetic of resistance to environmental stresses in Drosophila populations. Annu. Rev. Genet., 7: 239-265.

Parsons, P. A. (1962). Maternal age and developmental variability. J. Exp. Biol., 39:251-260.

Partridg, L.E.; Barrie, B.; Fowler, K. and French, V. (1994). Evolution and development of body-size and cell-size in Drosophila melanogaster in response to temperature. Evolution., 48:1269-1276.

Precht, H. J.; Christophersen, H.; Hensel, H. and Larcher, W. (1973). Temperature and Life. Berlin: Springer-Verlag. 
Schnebel, E. M. and Grossfield, J. (1986). Oviposition temperature range in four Drosophila species triads from different ecological backgrounds. Am. Midl. Nat., 16: 25-35.

Tantawy, A. O. and El Helw, M. R. (1970). Studies on natural populations of Drosophila. V. Correlated response to selection in Drosophila melanogaster. Genetics., 53:97-110.

Zatspina, O. G.; Velikodvorskaia, V.V.; Molodtsov, V.B.; Garbuz, D.; Lerman, D.N.; Bettencourt, B.R.; Feder, M.E. and Evgenev, M.B. (2001). A Drosophila melanogaster strain from sub-equatorial Africa has exceptional thermotolerance but decreased Hsp70 expression. J. Exp. Biol., 204: 1869-1881. 